\title{
PERANAN TINGKAT KECEMASAN TERHADAP MOTIVASI BERPRESTASI MAHASISWA
}

\author{
Hariyanto \\ Program Studi PGSD, Fakultas Keguruan dan Ilmu Pendidikan, \\ Universitas Kristen Petra \\ Email: hariyanto.mpd@petra.ac.id \\ Iman Subekti \\ Program Studi PGSD, Fakultas Keguruan dan Ilmu Pendidikan, \\ Universitas Kristen Petra \\ Email: imansubekti@petra.ac.id
}

\begin{abstract}
Abstrak
Perasaan takut dan cemas biasanya muncul saat seseorang dalam kondisi terdesak atau terancam. Dalam kondisi seperti ini kedua perasaaan tersebut (terutama rasa cemas) mendorong dan memampukannya untuk memberikan kinerja terbaik dan memecahkan masalah secara kreatif. Rasa cemas ini dikatakan menolong dirinya keluar dari masalah dan membuatnya berhasil. Di dunia pendidikan, hal ini dapat dikaitkan dengan bagaimana kecemasan mendorong mahasiswa untuk berprestasi. Dalam penelitian ini, peneliti ingin melihat bagaimana peranan tingkat kecemasan yang berbeda berpengaruh terhadap motivasi berprestasi mahasiswa. Skor kecemasan diperoleh dari tes TMAS (Taylor Manifest Anxiety Scale). Kemudian, skor-skor tersebut digolongkan tingkat kecemasannya berdasarkan standar deviasinya menjadi kecemasan rendah, sedang, dan tinggi. Skor motivasi berprestasi diperoleh melalui kuesioner motivasi berprestasi. Berdasarkan hasil analisis yang dilakukan, ditemukan bahwa ada perbedaan motivasi berprestasi mahasiswa yang sangat signifikan antar tingkat kecemasan yang berbeda.
\end{abstract}

Kata Kunci: kecemasan, motivasi berprestasi, mahasiswa

\begin{abstract}
Fear and anxiety typically rise when a person is in a danger or feels threatened. These feelings, specifically anxiety, can direct a person's behavior to gain his or her best performances and to solve problems creatively. It is aforementioned that anxiety facilitates a person to overcome difficulties and makes him/her success in his/her life. In education, it can be related on how anxiety motivates undergraduate students to strive for achievement in their study. The researcher attempted to discover how the role of difference levels of anxiety affects undergraduate students' achievement motivation. Taylor Manifest Anxiety Scale (TMAS) test was employed to measure students' trait anxiety and then the obtained scores were divided into three levels of anxiety, i.e. low, medium and high using standard deviation (SD). For students' achievement motivation scores was gathered from questionnaires.
\end{abstract}


Drawing on the result of the data analysis, the researcher concluded that there was a significant difference of achievement motivation of undergraduate students with difference levels of anxiety.

Keywords: anxiety, achievement motivation, undergraduate students

\section{PENDAHULUAN}

Manusia dalam rentang tertentu dalam hidupnya dapat mengalami kecemasan atau ketegangan sebagai reaksi yang wajar terhadap situasi yang menimbulkan stress/tekanan. Kecemasan semacam ini (dengan derajat tertentu) justru menolong fungsi keseharian manusia daripada menghambatnya sehingga membuat manusia terdorong untuk belajar saat menghadapi ujian, menjalani ujian fisik atau menyelesaikan suatu pekerjaan dengan waktu yang cukup lama demi mencapai target tertentu (Feldman, 1994).

Kecemasan ditandai dengan perasaan tidak menyenangkan dengan gejala penyerta berupa peningkatan fungsi-fungsi fisiologis dan perilaku menghindar (avoidance behavior). Fungsi ini sangat penting bagi manusia untuk bertahan hidup. Jika ada seseorang yang berenang di laut dan melihat seekor ikan hiu mendekat, rasa takut dan cemas merupakan suatu respon yang normal dan penting agar ia terhindar dari bahaya.
Akan tetapi, kecemasan semacam ini tidak dapat dibandingkan dalam intensitas, durasi, dan kekuatannya dengan orang yang mengalami gangguan kecemasan, yaitu gangguan yang dianggap sebagai bentuk-bentuk neurosis; suatu kelompok besar dari gangguan jiwa nonpsikotik dengan karakteristik adanya kecemasan yang tidak realistis dan masalah-masalah lain yang terasosiasi.

Maksudnya, meskipun sumber/objek kecemasan tersebut ada/nyata tapi kecemasan yang ditimbulkannya bukan dikarenakan obyek tersebut memang atau nyata-nyata berbahaya bagi/mengancam dirinya. Dengan kata lain, individu tersebut berpikir bahwa akan ada sesuatu yang buruk terjadi kepadanya (Halgin \& Whitbourne, 2010). Hal ini timbul akibat terjadinya asosiasi dalam pikirannya dari obyek tersebut sehingga membuatnya cemas. Asosiasi ini terjadi antara pengalaman masa lalu yang memicu kecemasan dengan rasa sakit atau hukuman yang mereka alami (Dollar \& Miller dalam Mischel, 1981). 
Dari penjelasan di atas, tampak bahwa kecemasan tidaklah selalu bersifat patologis. Kecemasan adalah emosi dasar manusia di samping gembira, sedih, marah dan lain-lain. Dalam derajat tertentu kecemasan diperlukan bagi kinerja individu untuk suatu tugas atau keperluan lain, karena seperti emosi dasar yang lain, kecemasan dapat memacu individu menuju kinerja terbaik (Clark \& Beck, 2012).

Kecemasan semacam ini, seperti dalam penjelasan yang sebelumnya, disebut sebagai kecemasan yang normal dan sehat, yang berfungsi sebagai tanda bahaya tentang keadaan jiwa dan tubuh manusia untuk dapat mempertahankan diri dalam lingkungan yang selalu berubahubah. Pada tingkat sedang, kecemasan justru meningkatkan daya upaya kesadaran serta menjaga tingkat prestasi kerja dan perilaku individu. Namun jika kecemasan itu tinggi dan individu tidak mampu mengendalikan atau meramalkan situasi dilingkungannya, maka timbul kecemasan yang patologis. Salah satu contoh di dunia pendidikan yang dapat menggambarkan fenomena ini yaitu penelitian yang dilakukan oleh Richard Alpert (1958, dalam Goleman 1996) pada tahun 1960-an.
Ia mempelajari kecemasan yang muncul pada saat ujian. Keinginannya tersebut di dorong karena sebagai mahasiswa, seringkali ketegangan saraf membuat nilai-nilai ujiannya jatuh; sementara koleganya, Ralph Haber, justru merasa bahwa tekanan sebelum ujian amat menolongnya untuk mencapai hasil yang lebih baik.

Penelitiannya, di antara studi-studi lainnya, memperlihatkan bahwa ada dua jenis mahasiswa yang cemas, mahasiswa yang kecemasannya menurunkan kemampuan akademis dan mahasiswa yang mampu bekerja dengan baik meskipun mengalami stres - atau dengan kata lain, walaupun stres, ia justru lebih berhasil.

Temuan Richard Alpert tersebut diperkuat dengan apa yang dikemukakan oleh Soemanto (1987). Ia menyatakan bahwa kecemasan seperti yang didefinisikan oleh Feldman (1994) sebagai ketegangan psikologis, merupakan unsur dasar dari motivasi yang disebutnya sebagai faktor internal, yang berupa perubahan yang terjadi diri seseorang.

Rasa tidak puas atau ketegangan psikologis ini bisa timbul oleh karena keinginan-keinginan untuk memperoleh 
penghargaan, pengakuan serta berbagai macam kebutuhan lainnya. Faktor internal ini biasanya mendahului unsur kedua yang disebut sebagai faktor eksternal dari motivasi yaitu berupa tujuan yang ingin dicapai seseorang. Tujuan itu sendiri berada di luar diri seseorang itu, namun mengarahkan tingkah laku atau tindakan orang tersebut untuk mencapainya.

Seseorang yang diasumsikan mempunyai kebutuhan untuk penghargaan dan pengakuan, maka timbullah tujuan untuk memenuhi kebutuhan tersebut. Dengan kata lain, di dalam motivasi terjadi peristiwa yang berurutan, faktor internal mendahului faktor eksternal, tapi bisa juga terjadi sebaliknya (tapi faktor eksternal hanya berfungsi sebagai perangsang timbulnya faktor internal). Di sini terlihat bahwa kecemasan adalah faktor psikologis yang berpengaruh terhadap motivasi seseorang.

Dari penjelasan di atas dapat terlihat bahwa kecemasan dapat mempengaruhi motivasi berprestasi mahasiswa. Hanya saja, peneliti tidak melihat dengan tingkat atau derajat yang bagaimanakah kecemasan dapat meningkatkan atau menurunkan motivasi berprestasi.
Oleh karena itu, penelitian ini bertujuan untuk mengetahui apakah ada perbedaan motivasi berprestasi antara mahasiswa yang memiliki tingkat atau derajat kecemasan yang berbeda.

\section{METODE}

Penelitian ini adalah penelitian komparatif yaitu penelitian yang bertujuan melihat perbedaan yang terjadi dengan cara membandingkan faktor-faktor yang berlibat (baik satu faktor atau lebih). Dalam penelitian ini ditetapkan tingkat kecemasan yang berbeda (rendah, sedang, dan tinggi) sebagai variabel bebas $(x)$; dan motivasi berprestasi sebagai variabel terikat $(y)$.

\section{Definisi Operasional}

Definisi operasional dari kecemasan adalah skor yang diperoleh subjek penelitian dari tes TMAS (Taylor Manifest Anxiety Scale). Sedangkan penentuan tingkat kecemasan rendah, sedang, dan tinggi didasarkan penghitungan standar deviasi (salah satu metode penentuan norma kelompok dalam statistik), yang memperhitungkan penyebaran skor-skor subjek dari rata-rata (mean) dengan satuan SD (simpangan deviasi), sehingga penggolongan tiga 
tingkat kecemasan tersebut adalah sebagai berikut:

a. Kecemasan rendah adalah skor kecemasan yang diperoleh subjek penelitian pada rentang $<-\mathbf{~ 1 ~ S D ~}$ (kurang /lebih kecil dari -1 SD)

b. Kecemasan sedang adalah skor kecemasan yang diperoleh subjek penelitian pada rentang -1 SD s/d +1 SD (antara -1 SD sampai dengan + $1 \mathrm{SD})$.

c. Kecemasan tinggi adalah skor kecemasan yang diperoleh subjek penelitian pada rentang > +1 SD (lebih besar dari +1 SD).

Pengelompokkan seperti penulis lakukan diatas dikarenakan di dalam penelitian oleh Taylor sendiri tidak disebutkan adanya kelompok dengan tingkat kecemasan tertentu. Ia hanya menyebutkan bahwa semakin tinggi skor yang didapat, semakin tinggi kecemasan subjek yang bersangkutan. Oleh karena itu maka pembuatan suatu norma kelompok dengan menggunakan SD oleh peneliti dimaksudkan agar kejelasan dan ketegasan akan tingkat kecemasan tersebut nampak, sehingga norma ini akan dapat digunakan pada subjek penelitian.
Definisi operasional dari motivasi berprestasi adalah skor yang diperoleh subjek penelitian dari kuesioner motivasi berprestasi. Semakin tinggi skor total yang diperoleh menunjukkan semakin tinggi motivasi berprestasi subjek yang bersangkutan.

\section{Populasi dan Sampel}

Populasi penelitian ini adalah mahasiswa/i Fakultas Psikologi Universitas Airlangga Surabaya sebanyak 267 orang dari 5 (lima) angkatan yang berbeda. Dengan menggunakan teknik combined sampling (teknik sampling kombinasi) yaitu proportional random sampling didapatkan jumlah sampel penelitian sebanyak 66 orang.

\section{Metode Pengumpulan Data}

Penelitian ini menggunakan dua macam alat pengumpul data. Pertama adalah alat ukur kecemasan yaitu TMAS (Taylor Manifest Anxiety Scale), dan yang kedua adalah kuesioner motivasi berprestasi.

Keduanya telah diuji dan telah memiliki indeks validitas dan reliabilitas yang memenuhi syarat untuk digunakan sebagai alat pengumpul data. 


\section{Teknik Analisis Data}

Peneliti menggunakan teknis analisis varian 1-jalur (one-way anova) untuk melihat perbedaan motivasi berprestasi dari tingkat kecemasan yang berbeda.

\section{HASIL DAN PEMBAHASAN}

1. Skor kecemasan

Skor total dari tes TMAS di analisis untuk mendapatkan standar deviasinya (SD), kemudian dilakukan pembagian rentang tingkat kecemasan rendah, sedang, dan tinggi seperti yang dijelaskan di definisi operasional. Hasil penghitungan dapat di lihat pada table 1 dan 2 sebagai berikut:

Tabel 1. Skor Total Tes TMAS

\begin{tabular}{llll}
\hline $\begin{array}{l}\text { Subjek } \\
\text { penelitian }\end{array}$ & $\begin{array}{l}\text { Skor total } \\
\text { kecemasan }\end{array}$ & $\begin{array}{l}\text { Rata- } \\
\text { rata }\end{array}$ & SD \\
\hline 66 & 1198 & 18,15 & 7,94 \\
\hline
\end{tabular}

Tabel 2. Rentang Tingkat Kecemasan

\begin{tabular}{ll}
\hline $\begin{array}{l}\text { Tingkat } \\
\text { kecemasan }\end{array}$ & $\begin{array}{l}\text { Kisaran skor } \\
\text { kecemasan }\end{array}$ \\
\hline Rendah & $\mathrm{x}<10,21$ \\
\hline Sedang & $10,21<\mathrm{x}<26,09$ \\
\hline Tinggi & $\mathrm{x}>26,09$ \\
\hline
\end{tabular}

2. Skor Motivasi Berprestasi

Berdasarkan tiga tingkat kecemasan yang ada pada tabel 2, dilakukan pengelompokkan jumlah individu yang termasuk dalam kelompok mahasiswa dengan tingkat kecemasan rendah, sedang atau tinggi. Kemudian skor rata-rata motivasi berprestasi (dari butir yang sahih) setiap kelompok dimasukkan dalam tabel untuk di analisis menggunakan anava 1-jalur. Hasil pengolahan skor motivasi dapat di lihat pada tabel 3 di bawah ini:

Tabel 3. Data Skor Motivasi Berprestasi

\begin{tabular}{lllr}
\hline $\begin{array}{l}\text { Tingkat } \\
\text { Kecema } \\
\text {-san }\end{array}$ & $\begin{array}{l}\text { Jml } \\
\text { Subjek }\end{array}$ & $\begin{array}{l}\text { Skor total } \\
\text { Motivasi } \\
\text { Berprestasi }\end{array}$ & $\begin{array}{l}\text { Rata- } \\
\text { rata }\end{array}$ \\
\hline Rendah & 14 & 1670 & 119,29 \\
\hline Sedang & 43 & 4748 & 110,42 \\
\hline Tinggi & 9 & 884 & 98,22 \\
\hline Total & 66 & 7302 & 110,64 \\
\hline
\end{tabular}

3. Pengujian Persyaratan Analisis

Dari hasil uji normalitas sebaran diperoleh hasil sebaran sampel adalah normal, dan hasil uji homogenitas varian menunjukkan bahwa variasinya homogen dari tiap-tiap kelompok. Dari hasil ini maka analisis data menggunakan analisis varian 1-jalur dapat dilakukan.

4. Deskripsi Hasil Analisis

Dari hasil analisis varian 1-jalur yang dilakukan, diperoleh nilai $F$ sebesar 13, 072 dengan peluang ralat $p$ sebedar 0,000.

Dapat dilihat pada tabel 4 berikut:

Tabel 4. Anava 1-jalur

\section{Tingkat Kecemasan}

\begin{tabular}{|c|c|c|}
\hline Rendah & Sedang & Tinggi \\
\hline 119,29 & 110,42 & 98,22 \\
\hline \multicolumn{3}{|c|}{ Anava 1-jalur $F=13,072 ; p=0,000$} \\
\hline
\end{tabular}


Untuk mengetahui lebih jauh perbedaan motivasi berprestasi antar tiap kelompok tingkat kecemasan, peneliti melakukan uji t. Hasilnya dapat dilihat pada tabel 5 sebagai berikut:

Tabel 5. Uji t (t-test)

Tingkat Rendah Rendah Sedang
Kecemasan -Sedang -Tinggi -Tinggi

\begin{tabular}{llll}
\hline Nilai $t$ & 2,480 & 5,891 & 3,411
\end{tabular}

\begin{tabular}{llll}
\hline Nilai $p$ & 0,015 & 0,000 & 0,001
\end{tabular}

\section{Diskusi dan Pembahasan}

Hasil penelitian menunjukkan tingkat kecemasan mahasiswa berdasarkan tes TMAS secara signifikan mempengaruhi motivasi berprestasinya.

Tes TMAS mengukur kecemasan yang bersifat trait (kecenderungan individu untuk cemas tanpa dipengaruhi oleh situasi), sehingga dapat dikatakan bahwa hasil dari skor TMAS menunjukkan sumber daya (dalam hal ini kecemasan) yang mampu memotivasi seseorang untuk berprestasi.

Mahasiswa yang merasa cemas dapat diketahui melalui adanya gejala-gejala fisik maupun psikologis, seperti yang diungkap melalui tes TMAS. Mahasiswa dengan tingkat kecemasan tinggi menunjukkan banyaknya gejala fisik dan psikologis yang dialaminya (Hilgard, 1983), seperti: jantung berdebar-debar, sakit kepala, nafsu makan menurun atau justru meningkat, muka menjadi merah dan gejala psikologis dapat berupa rasa takut, tidak tenang, tidak tenteram, bingung, mudah marah, mudah tersinggung, tidak dapat memusatkan perhatian dan sebagainya (Dariyo, 1998).

Penelitian ini mendukung pernyataan yang ditulis oleh Goleman (1996) yang menyatakan bahwa sumber daya mental ini (yaitu kecemasan) jika berlebihan ternyata justru menghambat seseorang untuk berprestasi. Seperti contoh pada kasus Richard Alpert di latar belakang masalah yang menyebutkan apabila orang terlalu disibukkan oleh kecemasan bahwa orang tersebut akan gagal dalam ujian yang sedang dihadapi, perhatian untuk menyusun jawaban akan berkurang, setara dengan besarnya kecemasan.

Kecemasan tersebut menjadi ramalan yang terbukti, mendorong ke arah malapetaka yang diramalkannya. Di pihak lain, kecemasan antisipatif-misalnya waktu ingin berpidato atau akan menghadapi ujian - untuk memotivasi diri guna mempersiapkan diri baik-baik, sehingga dapat melakukannya dengan sempurna.

Jika bacaan klasik dalam psikologi melukiskan hubungan antara kecemasan 
dan kinerja dalam model huruf $U$ terbalik, maka hubungan antara kecemasan dengan motivasi berprestasi dapat dilukiskan sebagai garis lurus yang menurun, seperti gambar berikut:

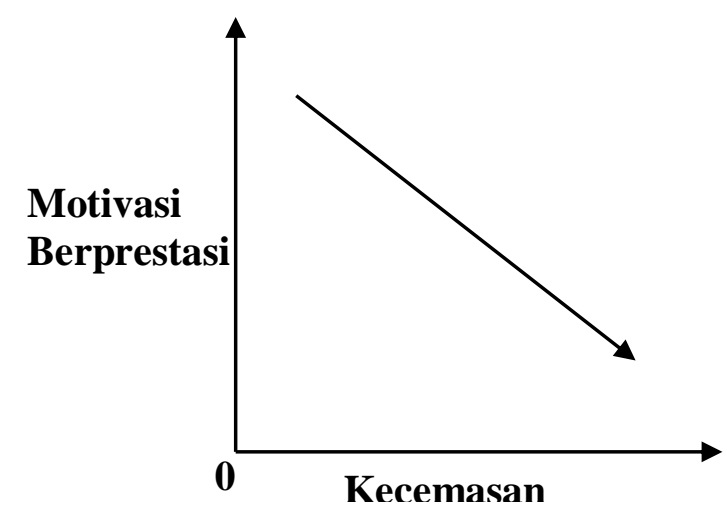

Gambar 1. Hubungan antara Motivasi Berprestasi dengan Kecemasan

Pada ujung kiri hubungan optimal antara kecemasan dan motivasi berprestasi, dengan sejumlah kecil saraf yang memancing prestasi luar biasa, sementara terlampau cemas -- ujung kanan -- merampok setiap usaha menuju kesuksesan, justru menurunkan motivasinya.

Dari hasil penelitian ditemukan bahwa mahasiswa dengan kecemasan rendah memiliki rata-rata skor motivasi berprestasi tertingi yaitu sebesar 119,29. Kemudian disusul oleh mereka yang termasuk dalam kelompok kecemasan sedang dengan rata-rata skor motivasi berprestasi sebesar 110,42. Dan rata-rata skor motivasi berprestasi terendah diperoleh kelompok mahasiswa dengan kecemasan tinggi yaitu sebesar 98,22.

Dan perbedaan itu bukan hanya dari nilai $F$ sebesar 13,072, melainkan juga tampak jelas dari hasil uji-t antar kelompok, yang menyebutkan bahwa perbedaan rata-rata skor motivasi antara kelompok mahasiswa yang memiliki tingkat kecemasan rendah dan sedang adalah signifikan (dengan nilai $\mathrm{t}$ sebesar 2,480); antara kelompok mahasiswa yang memiliki tingkat kecemasan rendah dan tinggi adalah sangat signifikan (dengan nilai $\mathrm{t}$ sebesar 5,891); dan antara mahasiswa yang memiliki tingkat kecemasan sedang dan tinggi adalah sangat signifikan (dengan nilai $\mathrm{t}$ sebesar 3,411).

Hasil uji perbedaan antar kelompok yang diperoleh yaitu signifikan dan sangat signifikan mendukung kerangka teoritik dalam penelitian ini, yaitu kecemasan diperlukan untuk dapat memotivasi seseorang untuk berprestasi, tetapi semakin tinggi tingkat kecemasan yang dialami orang tersebut akan menghalangi atau menghambatnya untuk berprestasi. 


\section{SIMPULAN}

Dari hasil analisis yang dilakukan, peneliti menyimpulkan ada perbedaan motivasi berprestasi yang sangat signifikan antara mahasiswa yang memiliki tingkat kecemasan rendah, sedang, dan tinggi. Bahkan saat dilakukan uji t antar kelompok, hasilnya perbedaan motivasi berprestasi antar kelompok berkisar antara signifikan dan sangat signifikan.

Hal ini menunjukkan bahwa kecemasan merupakan salah satu faktor penting dalam mendorong mahasiswa untuk berprestasi. Akan tetapi, jika kecemasan yang dialami mereka berlebihan, justru menghambat atau menghalangi mereka untuk memberikan usaha terbaik mereka untuk berprestasi.

\section{DAFTAR PUSTAKA}

Clark, D.A., \& Beck, A.T. (2012). The anxiety and worry workbook: The cognitive behavioral solution. New York, NY: Guilford Press.

Dariyo, A. (1998). Kepercayaan Diri dan Kecemasan Menghadapi Kelahiran Bayi Pada Perempuan Hamil Pertama. Jurnal Ilmiah Arkhe, th.III/no.5, hal 106-109. Fakultas Psikologi Universitas Tarumanegara.

Feldman, R.S. (1994). Essentials Understanding of Psychology, 2nd ed. New York: McGraw-Hill, Inc.
Goleman, D. (1996). Kecerdasan Emosional; Alih Bahasa: T. Hermaya, cetakan ke-1. Jakarta: Gramedia Pustaka Utama.

Halgin, R.P, \& Whitbourne, S.K. (2010). Psikologi abnormal: Perspektif klinis pada gangguan psikologis. Edisi ke-6. (A. Tus'yani, L.S. Sembiring, P.G. Gayatri, P. Sofyan, penerjemah.) Jakarta: Salemba Humanika

Hilgard, E.R., Atkinson, R.L., \& Atkinson, R.C. (1983). Introduction to Psychology. New York: Harcourt Brace Javanovich, Inc.

Mischel, Walter. (1981). Introduction to Personality, 3rd ed. New York: Holt, Rinehart and Winston, Inc.

Soemanto, W. (1987). Psikologi Pendidikan (Landasan Kerja Pimpinan Pendidikan). Jakarta: Bina Aksara 